\title{
HMGA2/RAD51B Fusion Gene
}

National Cancer Institute

\section{Source}

National Cancer Institute. HMGA2/RAD51B Fusion Gene. NCI Thesaurus. Code C99424.

A fusion gene that results from a chromosomal translocation $\mathrm{t}(12 ; 14)(\mathrm{q} 15 ; \mathrm{q} 22-24)$

which fuses exons 1-3 of the HMGA2 gene to the 3' portion of the RAD51B gene. This rearrangement is associated with uterine leiomyoma. 